\title{
Experimental Validation of Simplified Identification Method of Yield Function Using Circumscribing Polygon of Yield Locus and Its Application for Analysis of Sheet Metal Forming
}

\author{
Hideo TAKIZAWA ${ }^{1 *^{*}}$ and Shohei KoDAma ${ }^{2)}$
}

1) Department of Mechanical Engineering, Faculty of Fundamental Engineering, Nippon Institute of Technology

2) Graduate School, Mechanical Systems Engineering, Nippon Institute of Technology

Abstract: In this study, a method to identify the yield surface by three types of simplified material tests is proposed. The uniaxial tensile test, hydraulic bulge test, and plane strain tensile test are used in this method. A polygon circumscribing the equal plastic work contour can be defined by assuming the associated flow rule on the direction of the plastic strain rate. The parameters of anisotropic yield function are identified as a smooth curve inscribed in this polygon. This paper describes the details of these material testing methods. The yield surface of the cold-rolled steel sheet (SPCE) is identified by the proposed method and modeled with Yld2000-2d yield function. The model is compared to the stress points which are measured by the biaxial stress tests using cruciform specimen. Both yield loci agree well. Moreover, the yield function identified by the proposed method is applied to two types of simple sheet metal forming problems, the hole expansion test and deep-drawing of cylindrical cup. The results of finite element analysis are compared with the experimental results in both problems. The thickness strain on the hole edge in the hole expansion test and the ear height of the deep-drawn cup are evaluated. The results of the analysis using the modeled yield function agree with the experimental results qualitatively.

Keywords: carbon steel; sheet metal; material testing; yield locus; yield function; hole expansion test; deep drawing.

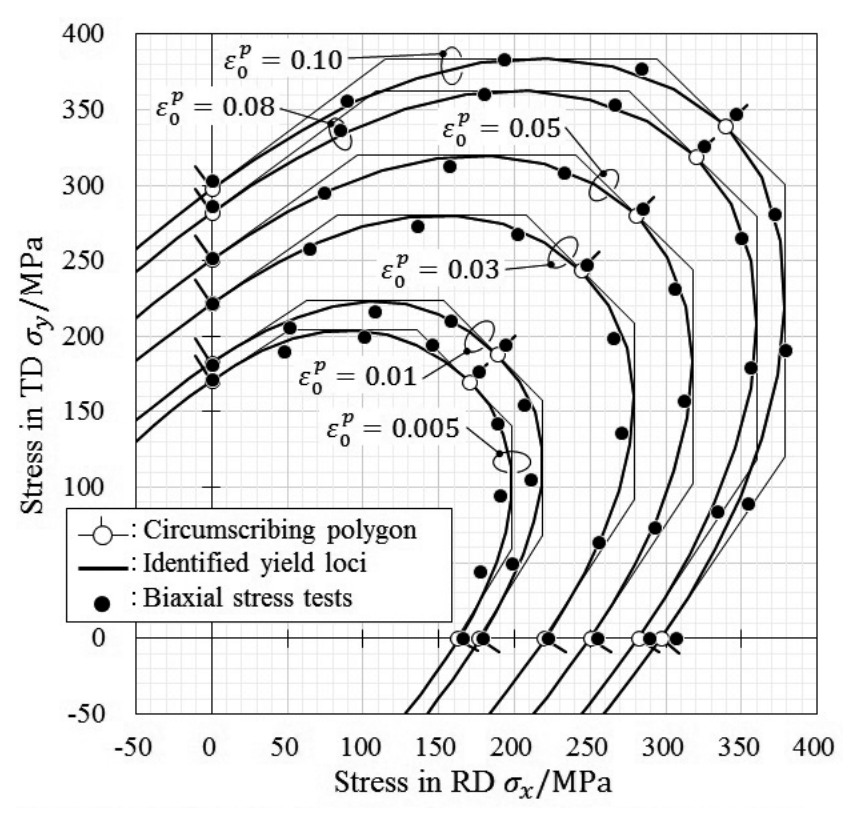

Received on Nov. 5, 2019 ; Accepted on Dec. 17, 2019

* Corresponding author. E-mail : htaki@nit.ac.jp, Address : Nippon Institute of Technology, 4-1 Gakuendai Miyashiro-machi Saitama 345-8501 


\title{
外接多角形による降伏関数簡易同定法の実験的検証と 板成形解析への応用
}

\author{
㴰澤 英男 ${ }^{1) *}$. 児玉 渉平 ${ }^{2)}$
}

Experimental Validation of Simplified Identification Method of Yield Function Using Circumscribing Polygon of Yield Locus and Its Application for Analysis of Sheet Metal Forming

Hideo Takizawa and Shohei Kodama

\section{1. 緒言}

板成形品の開発期間短縮のために, 金型設計段階での事 前予測による試作レス化が求められている。このためには 板成形シミュレーションの高精度化が必要である。板成形 解析では，材料モデリングの適否が解析精度に大きな影響 を与え, 特に塑性変形特性のモデル化では, 異方性降伏関 数を用いた精緻な材料モデルが必要となる ${ }^{1-3)}$ 。また，成 形中に負荷方向が反転する場合は，異方性降伏関数に加え て，移動硬化または複合硬化モデルも考慮する必要があ る ${ }^{4,5)}$ 。このような材料モデル化においては特殊な材料試験 が必要となる。成形中の鋼板は二軸応力下で変形が進行す るため，単軸引張試験だけでは，材料の異方性特性を適切 にモデル化することはできない。これに対して, 十字型試 験片または円管試験片を用いた二軸応力試験が提案されて いる ${ }^{6-8)}$ 。現在, 前者はISOとして規格化され ${ }^{9)}$, 今後の普 及が期待される。一方，これらの二軸応力試験には専用の 特殊試験設備が必要とされるため，現時点では，研究機関 での利用が多く，設計現場での解析を対象とした材料モデ リングの標準的な材料試験としては，充分に普及している とは言い難い。

異方性降伏関数の利用拡大のために, 著者らは, 一般的 かつ古典的な複数の材料試験法の組合せにより, 異方性降 伏関数を同定する簡易な方法を提案している。この方法で は,「単軸引張試験」および「液圧バルジ試験」に加え, 汎 用の引張試験機に専用治具を取りつけて行う「平面ひずみ 引張試験」により異方性降伏曲面の外接多角形を定義し, これを用いて異方性降伏関数を同定する ${ }^{10-12)}$ 。この簡易同 定法の妥当性については，材料試験の有限要素解析によ り，降伏関数が適切に同定できることを数值的に検証して いる ${ }^{13)}$ 。しかし，実験的検証は行われていない。
本報告では，各材料試験法の詳細を述べ，簡易同定法に よって実際の軟鋼板の降伏曲面を測定する。この方法で得 られた異方性降伏曲面モデルと既存の二軸引張試験法の実 験結果 ${ }^{14,15)}$ を比較し, 提案手法の妥当性について実験的検 証を行う。また, 同定した異方性降伏関数を用いて穴広げ 試験および円筒深絞り加工の有限要素解析を行い, 実験結 果との比較にもとづき, 簡易同定法による材料モデリング の有効性を示す。

\section{2. 外接多角形による簡易同定法の概要}

提案する降伏曲面の簡易同定法では, 単軸引張試験, 液 圧バルジ試験 (等二軸応力試験) および平面ひずみ引張試 験の三種類の材料試験を用いる。Fig.1 1本同定法の模式説 明図を示す。図は板材の圧延方向 (RD) および圧延直交方 向 (TD) の垂直応力 $\left(\sigma_{x}, \sigma_{y}\right)$ による応力平面を示す。

単軸引張状態での降伏点は, 各垂直応力の軸と降伏曲面 の交点を示す。また，等二軸応力状態の降伏点は， $\sigma_{x}=\sigma_{y}$

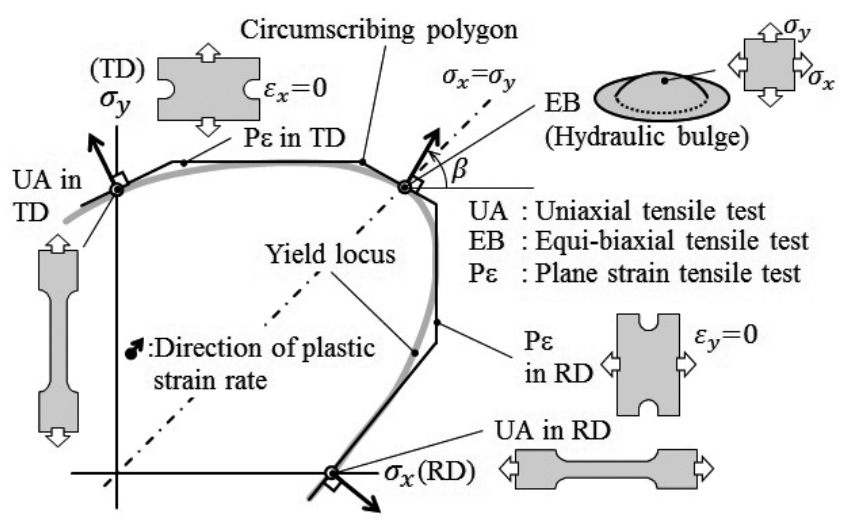

Fig. 1. Simplified method to model anisotropic yield function.

2019年 11 月 5日受付 2019年12月17日受理（Received on Nov. 5, 2019; Accepted on Dec. 17, 2019)

1）日本工業大学基幹工学部機械工学科 (Department of Mechanical Engineering, Faculty of Fundamental Engineering, Nippon Institute of Technology)

2) 日本工業大学大学院工学研究科機械システム工学専攻 (Graduate School, Mechanical Systems Engineering, Nippon Institute of Technology)

* Corresponding author. E-mail : htaki@nit.ac.jp, Address : Nippon Institute of Technology, 4-1 Gakuendai Miyashiro-machi Saitama 345-8501 
の直線と降伏曲面の交点を示す。塑性ひずみ増分 $\left\{d \varepsilon^{p}\right\}$ が 降伏曲面の法線方向と一致すること (関連流れ則) ${ }^{16,17)}$ を仮 定すると，塑性ひずみ増分比の実測值から，これらの応力 点における降伏曲面の接線が定まる。また，RDおよびTD の平面ひずみ引張状態では，引張り方向に直交する塑性ひ ずみ増分がゼロとなる。このため，降伏曲面が外に凸の滑 らかな関数であることを仮定すれば，降伏曲面の各垂直応 力軸方向への極大值を定めることができる。このようにし て応力空間に 3 つの応力点と 5 本の外接線が定義され，こ れに内接する滑らかな曲線として降伏曲面を同定すること ができる。なお，本研究では，塑性仕事等価説 ${ }^{16)}$ を仮定し， 同一の塑性変形仕事における応力点の集合を降伏曲面とみ なして ${ }^{18,19)}$ ，降伏曲面の外接多角形を定義する。

\section{3. 供試材および実験方法}

\section{$3 \cdot 1$ 供試材}

供試材には, 公称板厚 $1.2 \mathrm{~mm}$ の深絞り加工用冷間圧延 鋼板 (SPCE) を用いる。この供試材は, 日本鉄鋼協会「先 進的多軸応力試験による鋼板成形の高度化研究会」 $\rfloor^{20)}$ で共 通サンプルとして提供された鋼板であり，同一ロットの板 材の降伏曲面 (等塑性仕事面) が二軸応力試験によって測 定されている ${ }^{14,15)}$ 。本研究での試験片採取のレイアウト模 式四を Fig. 2 に示す。

\section{$3 \cdot 2$ 実験方法}

簡易同定法で用いる 3 種類の材料試験方法について，以 下，詳細に説明する。いずれの試験においても，ひずみの 測定には，塑性域ひずみゲージ（東京測器研究所（株）製 YFLA-2）を用いる。各試験を 5 回実施し，平均值を求める。

(1) 単軸引張試験 (UA : Uni-Axial tensile test)

試験にはJIS Z2241の 13 B 号試験片を用いる。Fig.2に示 したように RD から TDへ $15^{\circ}$ 毎の計 7 方向の単軸引張試験 を実施し, 異方性主軸座標系におけるせん断応力 $\tau_{x y}$ の降伏 関数への寄与を測定する。いずれの試験においても試験片 中央部に引張り方向および試験片幅方向の二方向のひずみ
ゲージを貼付し，これらのひずみから Lankfordの $r$ 值を測 定する。

(2) 液圧バルジ試験 (等二軸応力試験. EB：Equi- Biaxial tensile test)

液圧バルジ試験は, 周囲をビードで固定した板材の片面 に液圧を加えることで，円孔ダイス側へドーム状に板材を 膨らませ，頭頂部に等二軸応力を与える試験法である。板 材に強い異方性がある場合, 完全な等二軸応力状態をつ くることは困難であることが指摘されているが ${ }^{21)}$ ，ここで は，近似的に等二軸応力状態を仮定する。

Fig.3 に試験片と金型の寸法および実験の様子を示す。試 験片および金型の寸法は吉田による解析 ${ }^{21)}$ を参考にした。 試験片中央に RD およびTD方向のひずみゲージを貼付す る。また, 写真に示すように四点式 (固定点 3 点と変位測定 点 1 点）の曲率計を試験片頭頂部に乗せて, 外表面の曲率 半径を測定する。試験から得られる負荷圧力 $p$, 外表面の 二軸ひずみ $\varepsilon_{s x}, \varepsilon_{s y}$ および外表面の曲率半径 $\rho_{s}$ を用いて, 等 二軸応力 $\sigma^{\mathrm{EB}}$ は，以下の式により算定される。

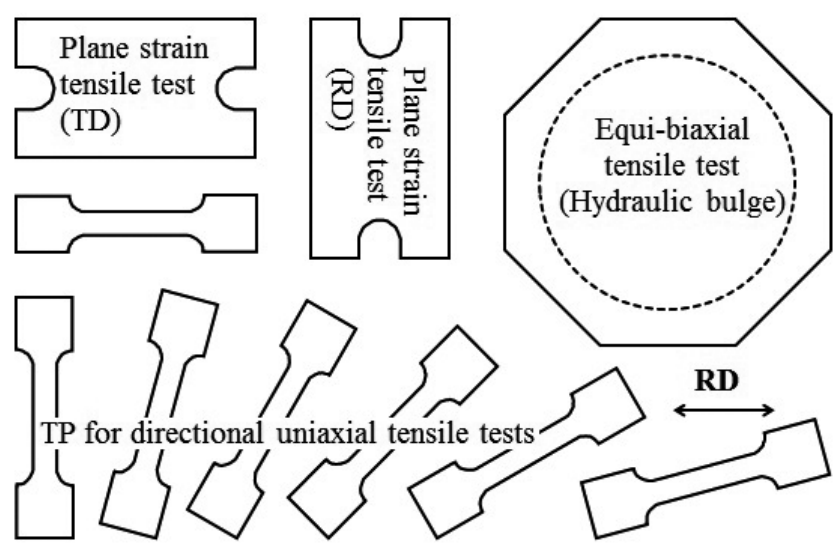

Fig. 2. Layout of specimens for proposed materials tests.

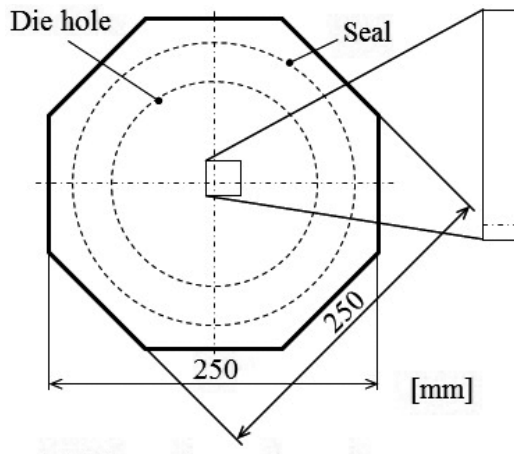

(a) Dimensions of specimen

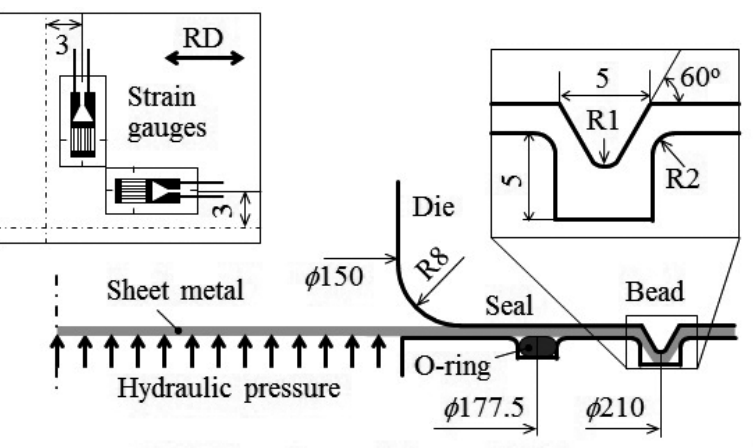

(b) Dimensions of die and holder

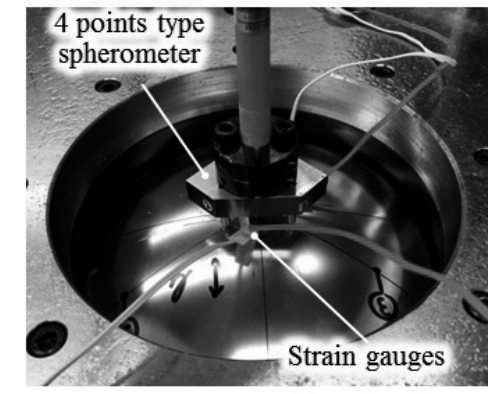

(c) Photograph of hydraulic bulge test

Fig. 3. Dimensions and photograph of hydraulic bulge test. 


$$
\begin{aligned}
& \sigma^{\mathrm{EB}}=\frac{p\left(\rho_{m}-t / 2\right)^{2}}{2 \rho_{m} t} \\
& t=t_{0} \exp \left(-\varepsilon_{m x}-\varepsilon_{m y}\right), \quad \rho_{m}=\rho_{s}-\frac{t}{2} \\
& \varepsilon_{m x}=\varepsilon_{s x}-\frac{t}{2 \rho_{m}}, \quad \varepsilon_{m y}=\varepsilon_{s y}-\frac{t}{2 \rho_{m}}
\end{aligned}
$$

ここで, $t$ は板厚, $\rho$ は曲率半径を示し, 下付き添字の $s$ は外 表面での測定值を, $m$ は板厚中央面の值を示す。これらの 式は非線形連立方程式となるため, 数回の収束計算を行っ て, 等二軸応力 $\sigma^{\mathrm{EB}}$ を求める。

(3) 平面ひずみ引張試験 ( $\mathrm{P} \varepsilon$ : Plane strain tensile test)

平面ひずみ引張試験では, 幅広の試験片を短いチャック 間距離で把持し，幅方向変形を拘束した状態で試験片を 引っ張る ${ }^{22,23)}$ 。幅広試験片を把持するための専用のチャッ クが必要となるが, 試験装置としては標準的な引張試験機 で実施できる。Fig.4に平面ひずみ引張試験の試験片形状と 試験の様子を示す。通常の引張試験で用いられるクサビ式 チャックを参考に, 最大 $150 \mathrm{~mm}$ 幅の試験片を把持できる チャックを設計した。平面ひずみ引張試験はRDと TDの 2 方向についてそれぞれ実施する。

平面ひずみ引張試験で生じる試験片の減肉は, 切久き 間の応力評価部分だけにとどまらず，チャック内部でも 生じる。このためチャック部から材料が引き出され, 正確 な平面ひずみ状態の応力測定ができない ${ }^{24)}$ 。これを改善す るために, 図に示すように応力評価領域 (切欠き部) と上 下 $4 \mathrm{~mm}$ を除いて試験片に補強板を接着し, 試験片の変形 を応力評価領域に限定させる。補強板にはチャック歯が喰 い付き易いアルミ合金 (A5052-H32, $t=1.0 \mathrm{~mm})$ を用い, 2 液アクリル系接着剤（セメダイン（株）製，メタルロック Y611）により試験片の両面に補強板を接着した。なお，接 着後に $60^{\circ} \mathrm{C} て ゙ 1$ 時間の保温を行い, 接着力の安定化を困っ た。
また，切欠き部近傍ではひずみ場の乱れが生じるため, 平面ひずみ応力の算出精度が低下することが懸念される。 差分荷重による正確な平面ひずみ応力の算出についても検 討しているが ${ }^{25,26)}$, 有限要素法解析では, 試験片幅 $100 \mathrm{~mm}$ の単独の平面ひずみ引張試験でも応力の真值と測定值の誤 差は $1 \%$ 以下であるため, 今回の実験には差分荷重法は適 用していない。

なお, 平面ひずみ引張試験片の幅方向变形を拘束するた めの幅方向応力 $\sigma_{w}$ は実験的に測定することはできない。し かし, 平面ひずみ状態であるため, 幅方向の塑性ひずみ増 分 $d \varepsilon_{w}^{p}$ をゼロとすれば, 幅方向応力 $\sigma_{w}$ は塑性仕事へ影響し ない。よって, 幅方向応力 $\sigma_{w}$ の不明は, 塑性仕事算出の障 壁にはならない。

以上，述べた実験方法によって得られる降伏曲面の同定 誤差については, 有限要素解析を用いて検証を行ってい る ${ }^{13)}$ 。

\section{4. 簡易同定法による降伏曲面同定とその検証}

\section{$4 \cdot 1$ 等塑性仕事面の外接多角形の算出}

Fig.5に各試験で貼付したひずみゲージにより測定され たひずみ履歴を示す。平面ひずみ引張試験においては, 試 験片幅方向のひずみは小さく, 目的とした平面ひずみ状態 が再現されている。また, 液圧バルジ試験の結果は, やや ばらつきが大きいものの，ひずみ比は，ほほ $1 ： 1$ となって いる。Fig.6に各試験で得られた真応力一真塑性ひずみ曲線 を示す。 RD, TDともに単軸引張が最も低く, 等二軸引張 および平面ひずみ引張の真応力一真塑性ひずみ曲線は, ほ ぼ同程度のレベルを示している。

本研究では, 塑性仕事等価説を仮定し, 等塑性仕事面を 降伏曲面とみなす。外接多角形を描くための等塑性仕事の 算出方法説明図を Fig.7 に示す。各試験における真応力一 真塑性ひずみ曲線を積分し, 単位体積あたりの塑性仕事 $W_{0}$ が等しくなる応力值を用いて外接多角形を定義する。降伏

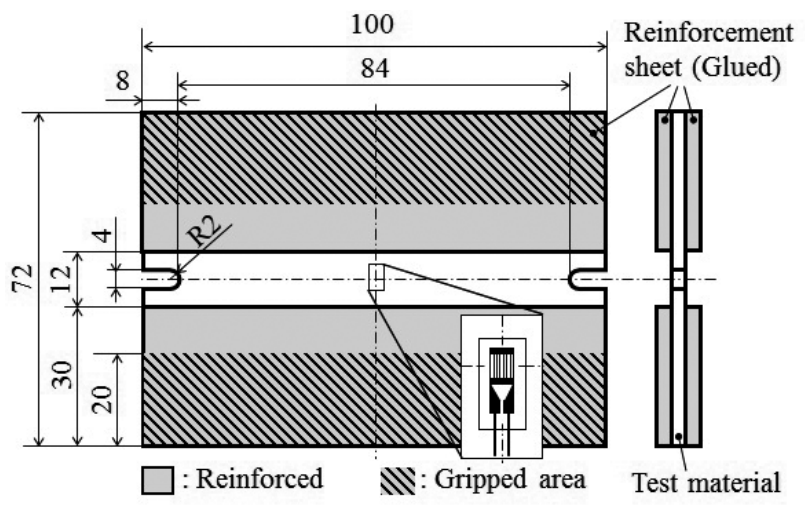

(a) Dimensions of specimen

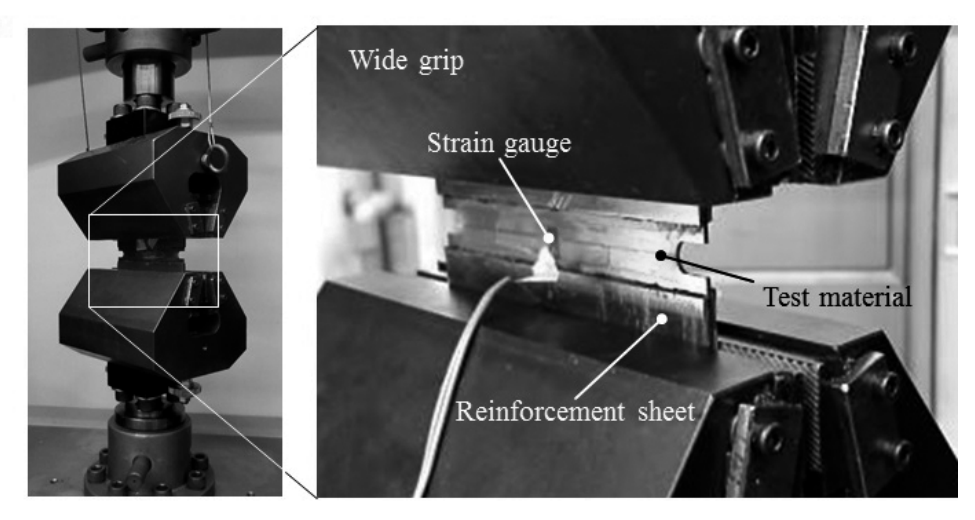

(b) Photograph of plane strain tensile test

Fig. 4. Dimensions of specimen and wide grips on plane strain tensile test. 


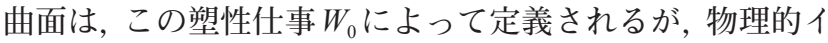
メージを明確にするため, RDの単軸引張試験に打ける真

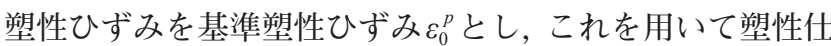
事レベルを表す ${ }^{8)}$

Fig.8に細い実線で簡易同定法によって算出された等塑

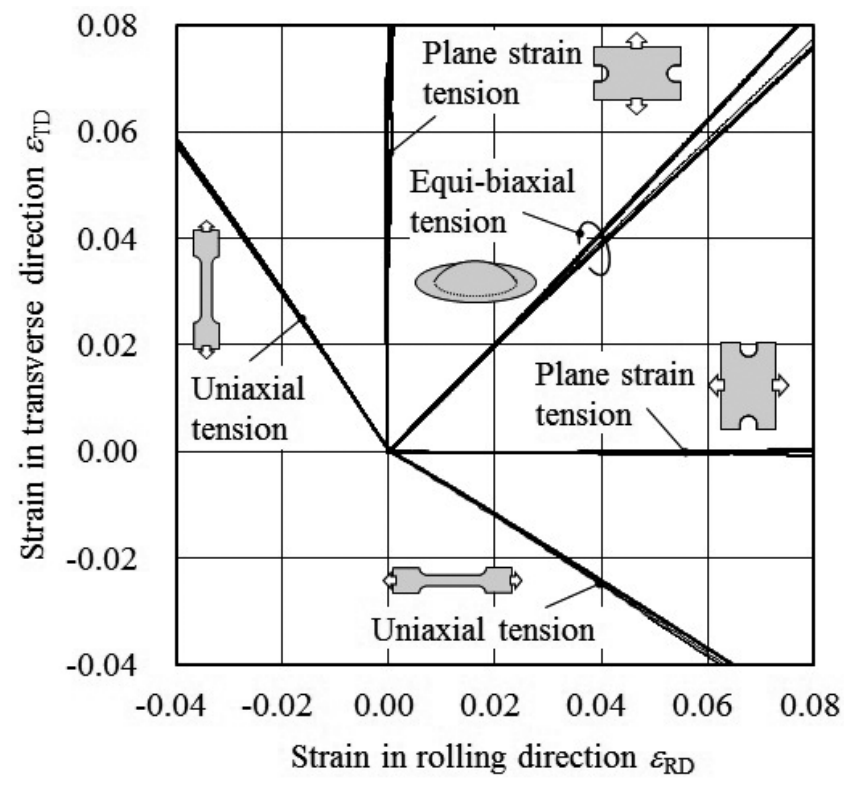

Fig. 5. Strain paths measured by strain gages in uniaxial, plane strain and equi-biaxial tensile tests.
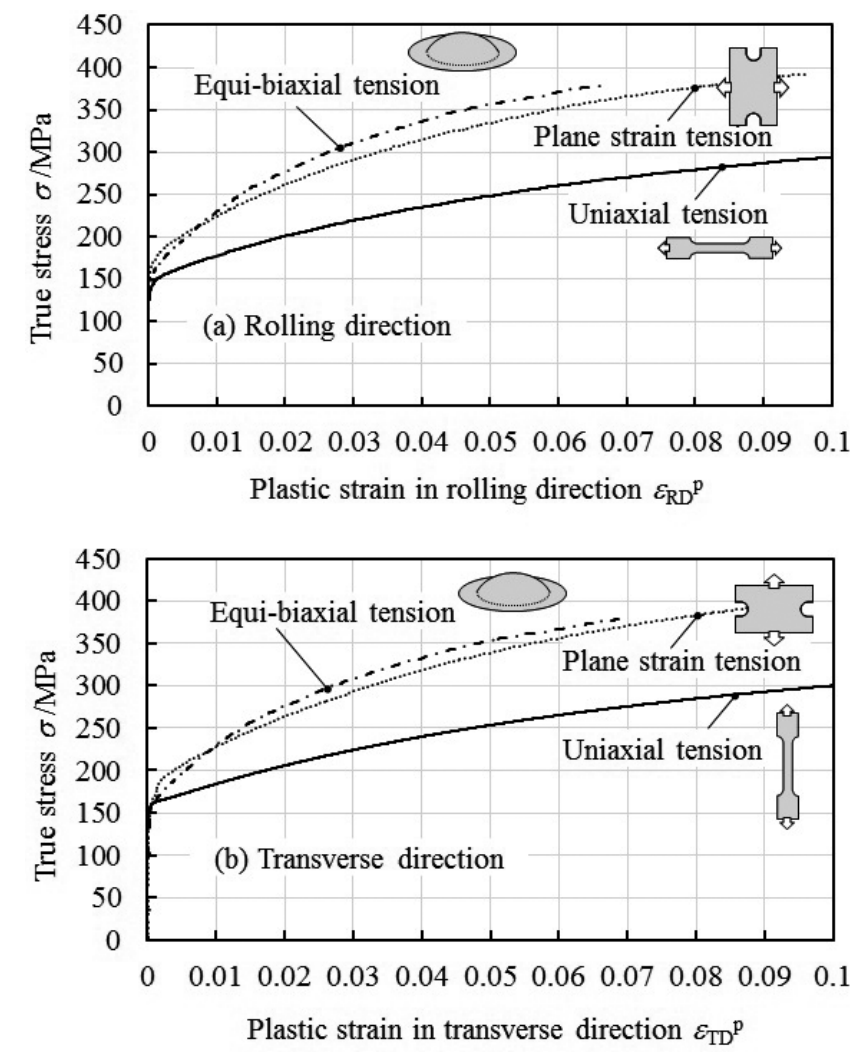

Fig. 6. Stress-strain curves in uniaxial, plane strain and equibiaxial tensile tests. (a) rolling direction and (b) transverse direction.
性仕事面の外接多角形を示す。図中の○印は単軸および等 二軸引張試験に打ける等塑性仕事点を示し, ○につけた短 い線分は塑性ひずみ増分方向 (すなわち降伏曲面の法線方 向）を示している。塑性仕事の小さい $\varepsilon_{0}^{p}=0.005$ から 0.03 ではわずかに外接多角形の形状変化を伴うものの, $\varepsilon_{0}^{p}=$ 0.03 以降は大きな形状変化は見られない。

\section{$4 \cdot 2$ 降伏関数の同定}

外接多角形に内接する滑らかな曲線として降伏関数を 同定する。降伏関数にはBarlatらが提案したYld2000-2d $\mathrm{d}^{27}$ を用いる。Yld2000-2dの材料パラメータは，係数 $\alpha_{1} \sim \alpha_{8}$ と 指数 $M$ の計 9 個である。これらのパラメータを定めるため に, 実験值と降伏関数モデルの誤差の二乗和として, 以下 に示す誤差関数 $\psi$ を定義する。

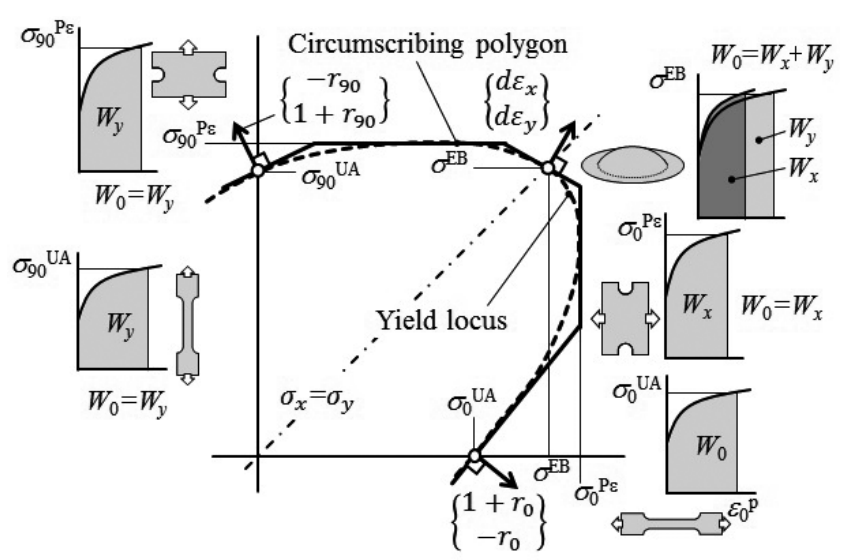

Fig. 7. Schematic illustration for circumscribing polygon of equal plastic work contour.

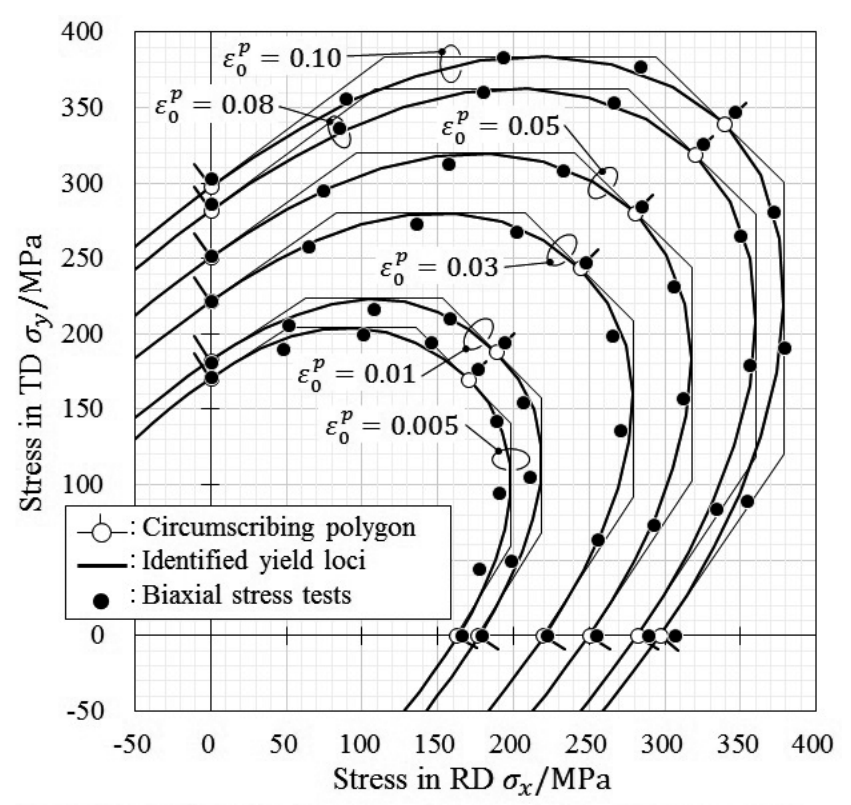

Fig. 8. Identified yield loci by circumscribing polygons and stress points measured by biaxial stress tests. 


$$
\begin{aligned}
\psi= & \frac{w_{\sigma}}{\sigma_{0}} \sqrt{\sum_{i=0}^{6}\left(\sigma_{15 i}^{\mathrm{UA}}-\tilde{\sigma}_{15 i}^{\mathrm{UA}}\right)^{2}+\sum_{i=0}^{1}\left(\sigma_{90 i}^{\mathrm{P} \varepsilon}-\tilde{\sigma}_{90 i}^{\mathrm{P} \varepsilon}\right)^{2}+\left(\sigma^{\mathrm{EB}}-\tilde{\sigma}^{\mathrm{EB}}\right)^{2}} \\
& +w_{\beta} \sqrt{\sum_{i=0}^{6}\left(\beta_{15 i}^{\mathrm{UA}}-\tilde{\beta}_{15 i}^{\mathrm{UA}}\right)^{2}+\left(\beta^{\mathrm{EB}}-\tilde{\beta}^{\mathrm{EB}}\right)^{2}}
\end{aligned}
$$

ここで, $\sigma$ は応力值を, $\beta$ は降伏曲面の外向き法線方向 (Fig.1 参照)の角度を $\mathrm{rad}$ 単位で表した值をそれぞれ示す。 右上添字のUA, EB打よびP $\varepsilon$ は, それぞれ単軸引張り, 等 二軸引張りおよび平面ひずみ引張りの各試験での值を示 す。また，右下添字は単軸および平面ひずみ引張試験にお ける RD と引張り方向のなす角 $\theta$ (単位ぱ) を示す。波線 (〜) 付きの変数はモデル化した降伏関数の值を, 波線無 しの值は材料試験で測定された值を示す。 $w_{\sigma}$ および $w_{\beta}$ は 応力値と法線方向のそれぞれの䛊差に対する重みであり， ここでは $w_{\sigma} / w_{\beta}=2$ を用いた。この值は, 応力単位における 約 $1 \%$ の誤差と塑性ひずみ増分方向に打ける $1^{\circ}(0.0175 \mathrm{rad})$ の誤差をほぼ同等に評価することを意味している。

この誤差関数 $\psi$ を最小化する降伏関数の材料パラメー タ求めることで降伏関数を同定する。誤差最小化計算に は, Microsoft社の表計算ソフト Excelに組み込まれている Solver機能の大域最適解探索ツールを用いた。

Fig.8に各等塑性仕事で同定した降伏関数モデルによる 曲線を太い実線で示す。すべての等塑性仕事レベルで, 3 つの応力点を通り多角形に内接する滑らかな降伏曲面を, Yld2000-2d降伏関数で表現できている。また, Fig.9に引張 方向を変化させた場合の単軸引張試験の流動応力と $r$ 值に ついて実測值と降伏関数モデルの比較を示す。深絞り用鋼 板であるため, 流動応力の面内異方性は比較的低い。応力 值についてはYld2000-2d降伏関数で精度よく近似できて いるが, $r$ 值については, 面内分布の傾向は表現できている ものの, 定量的には充分な近似とは言い難い。より近似精 度を向上させるためには, Yld2000-2d よりも材料パラメー 夕数の多い, より複雑な降伏関数 ${ }^{28,29)}$ を用いる必要がある。

\section{$4 \cdot 3$ 二軸引張試験結果との比較}

本研究で用いた供試材と同一ロットの鋼板の等塑性仕事 点が, 十字形試験片による二軸応力試験および円管試験片 による二軸バルジ試験によって求められている ${ }^{14,15)}$ 。この 結果を参照值として, 本提案手法によって同定された降伏 関数モデルを評価する。Fig. 8 に二軸応力試験で測定した参 照値をつで示す。

簡易同定法で得られた降伏曲面と二軸応力試験による参 照值を比較すると, 塑性変形の小さい $\varepsilon_{0}^{p}=0.03$ までは, 簡 易同定法による降伏曲面の応力がやや高めにモデル化され ているが, 大きな塑性変形の領域では, 同定された降伏曲 面は, 二軸応力試験の実測值とほぼ一致している。簡易同 定法によって同定した降伏関数は, 既存の二軸応力試験に よって測定された等塑性仕事点とよい一致を示しており,
本手法により適切な降伏関数が同定できる。

\section{5. 板成形解析への適用}

ここでは, 基礎的な板成形実験として穴広げ試験および 円筒深絞り加工を取り上げ, 同定した降伏関数を用いた有 限要素解析結果と成形実験結果を比較する。これにより, 簡易同定法でもとめた降伏関数の板成形解析に打ける有効 性を確認する。穴広げ試験では, 板材は面内二方向とも引 張応力状態 (応力空間の第一象限) で変形する。一方, 深絞 り加工のフランジ部では, 成形中に引張りおよび圧縮の応 力が同時に生じる (応力空間の第二および第四象限)。この 二つの実験では板成形に打ける代表的な応力状態が生じる ため,これらを検証として用いる。

Table 1 に簡易同定法により求めた基準塑性ひずみ $\varepsilon_{0}^{p}=$ 0.08に打けるYld2000-2d降伏関数の材料パラメータを示
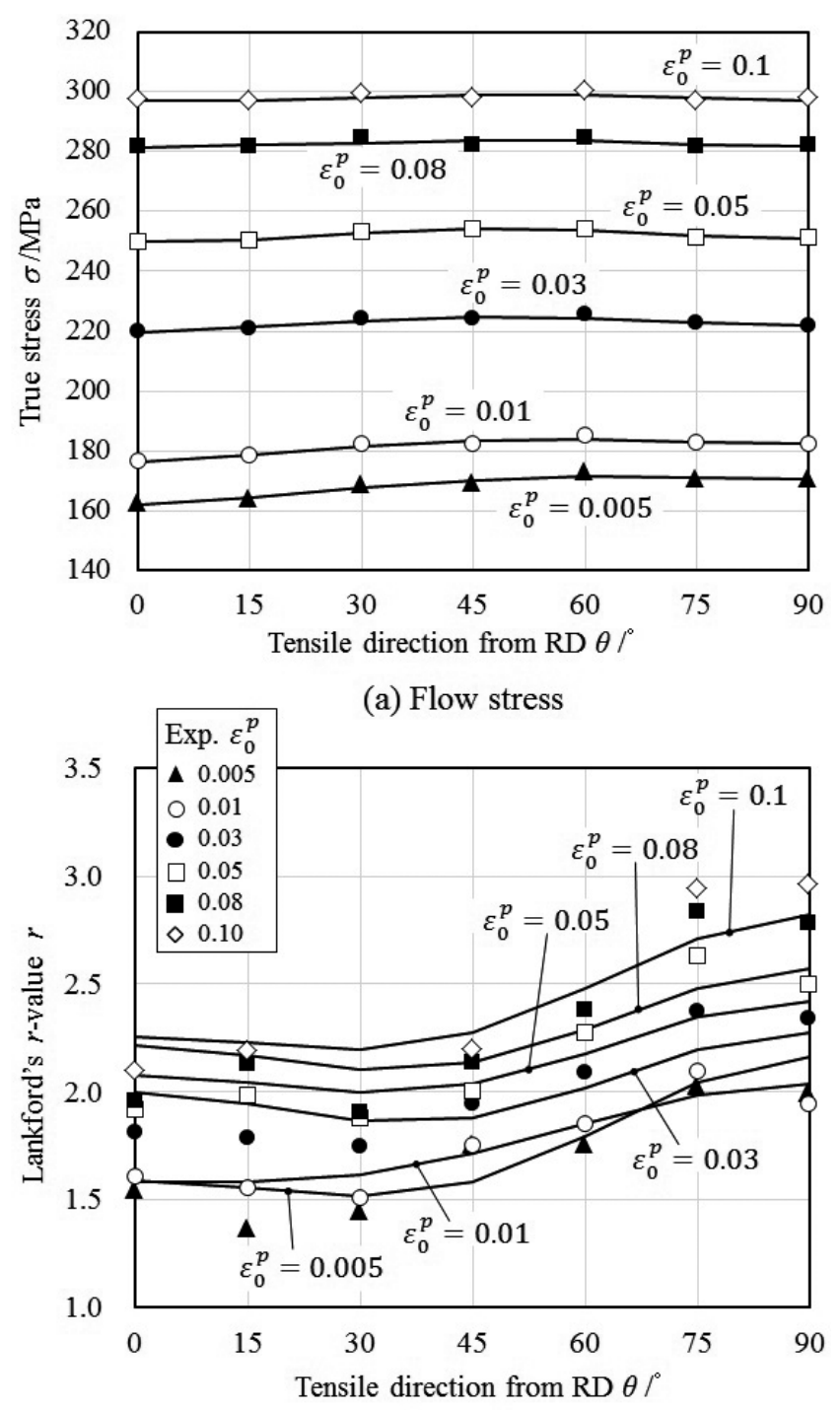

(b) $r$-value

Fig. 9. Identified yield function and uniaxial tensile test data of in-plane distribution of (a) flow stress and (b) $r$-value. 
す。また，弾性特性およびモデル化した変形抵抗曲線のパ ラメータを同表に示す。硬化則には等方硬化を仮定する。 以下の成形解析に扎いては，これらの材料パラメータを用 いる。解析には汎用非線形有限要素解析コードMarcを用 いる。対称性を考慮して $1 / 4$ 形状でモデル化し，板材には 平面応力を仮定して薄肉シェル要素を，金型には剛体曲 面を，それぞれ用いる。Yld2000-2d降伏関数は，ユーザサ ブルーチンライブラリUMMDpを用いて解析に組み込ん だ ${ }^{30)}$ 。

\section{$5 \cdot 1$ 穴広げ試験による検証}

穴広げ試験の実験条件および解析モデルを Fig.10に示 す。実験結果は，今回の供試材と同一ロット材を用いた実 験の文献值 ${ }^{14)}$ を引用する。解析における摩擦係数は $\mu=$ 0.15 を用いた。

パンチストローク $u=30.0 \mathrm{~mm}$ まで加工した際の，変形 前の孔縁から $2 \mathrm{~mm}$ の位置における板厚方向真ひずみ $\varepsilon_{z}$ の

Table 1. Identified material parameters for SPCE.

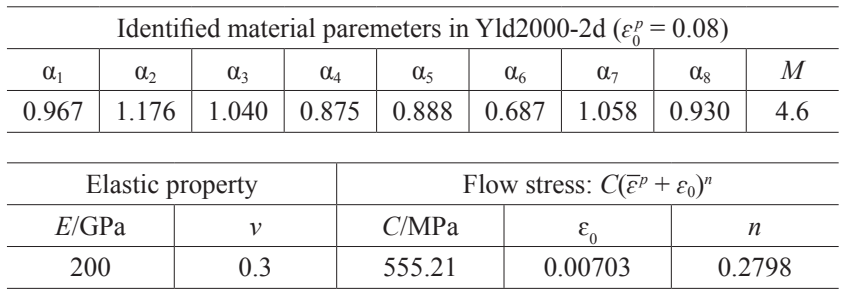

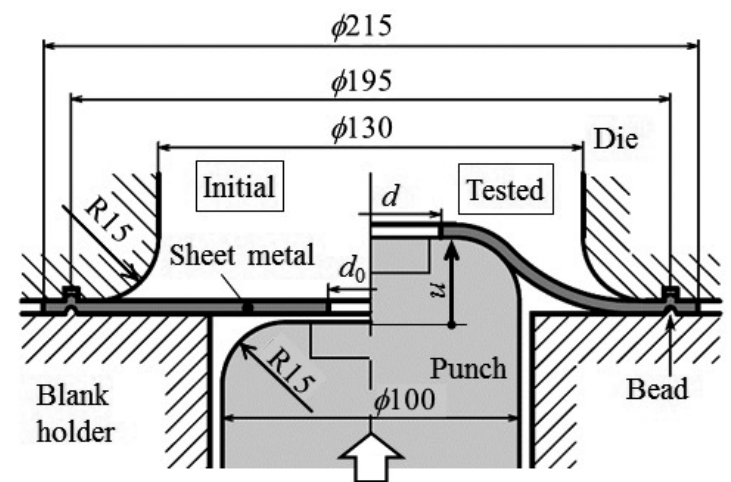

(a) Dimensions of tools

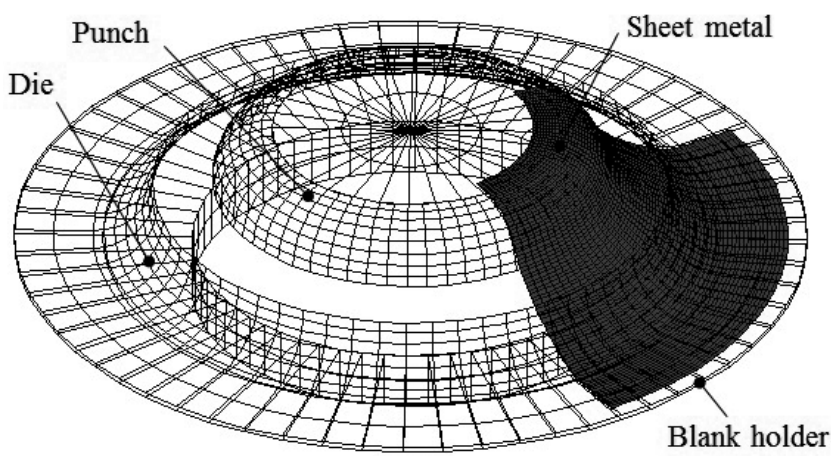

(b) Finite element model

Fig. 10. Experimental set-up and FEA model for hole expansion test.
周方向分布をFig.11に示す。実測結果を○で，解析結果を 実線でそれぞれ示す。実測結果に対して全体的に解析結果 の板厚減少が低く算出される傾向がある。しかし，解析に よる板厚ひずみ $\varepsilon_{z}$ の分布形態と変動幅は実験結果によく一 致している。提案手法でモデル化した降伏関数で，板材の 面内異方性の影響は定性的に表現できている。

\section{$5 \cdot 2$ 深絞り加工による検証}

円筒深絞り加工の成形条件および実験の様子を Fig.12 示す。絞り比 $D R$ (ブランク径/パンチ径) は 1.8 である。実 験では金型と素板の間に潤滑油を用いており，解析では摩 擦係数を $\mu=0.0,0.1$ および 0.2 の 3 条件に設定した。しわ 抑え力は $B H F=10 \mathrm{kN}$ として，実験では写真に示すように 支柱に組み込んだ圧縮ばねでしわ抑え力を与えた。

Fig.13に実験と解析の荷重一ストローク曲線の比較を示 す。実験と解析の曲線の傾向はよく一致しており，荷重の 比較から摩擦係数 $\mu$ は概ね 0.1 と 0.2 の間にあると推定され る。Fig.14に実験と解析 $(\mu=0.1)$ の成形後のカップ形状の 比較を示す。解析結果には相当塑性ひずみ分布を示す。面 内異方性が比較的低い材料であるため，顕著な相当塑性ひ

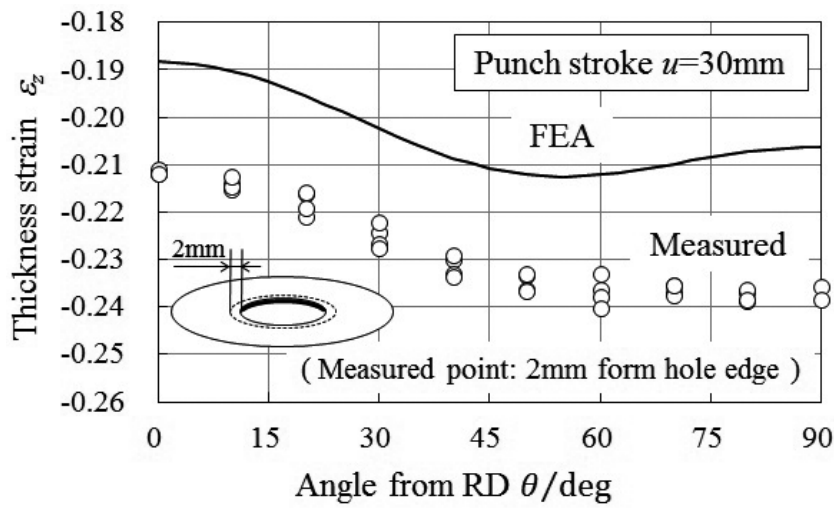

Fig. 11. Comparison between measured and analyzed thickness strain along the hole edge.

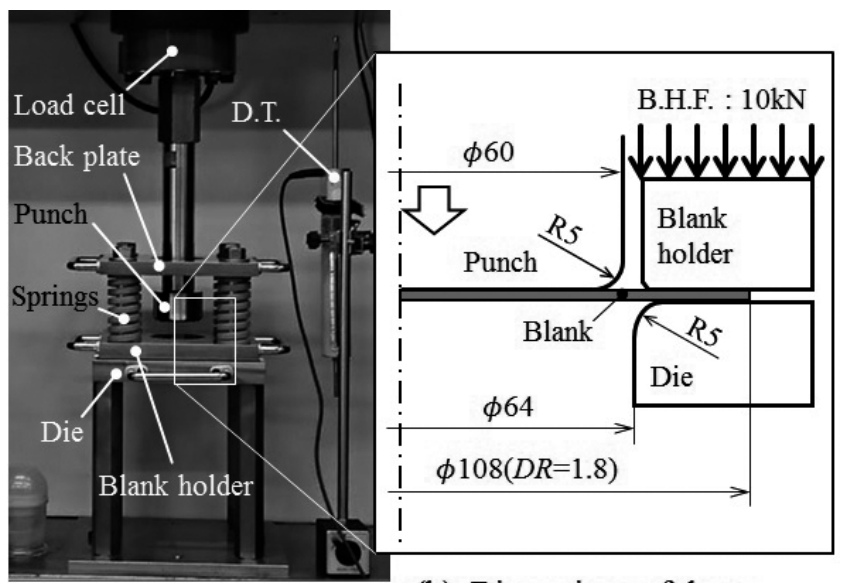

(a) Experimental apparatus

(b) Dimensions of deepdrawing test

Fig. 12. Experimental set-up for deep-drawing test. 
ずみの偏りやカップ高さの変動 $(耳)$ は見られないが, $\mathrm{RD}$ と TDの中間 $\left(45^{\circ}\right.$ 方向) でわずかな谷が生じており, 解析 でも同様の傾向が見られる。これを定量的に評価するため に試験片全周のカップ高さを測定し, 解析と比較した結果 を Fig.15に示す。解析には薄肉シェル要素を用いているた め, 板厚方向圧縮応力は考慮されていない。このため, 解 析結果のカップ高さは全体的にやや低く算出される傾向に ある。これを考慮すれば, 解析によって予測した耳高さの 分布形態打よび変動幅は実測結果とよく一致している。

簡易同定法では試験法の制約から応力空間における第一 象限での測定結果にもとづいて降伏曲面をモデル化してい る。これに対して, 深絞り成形に打ける主たる変形は，フ

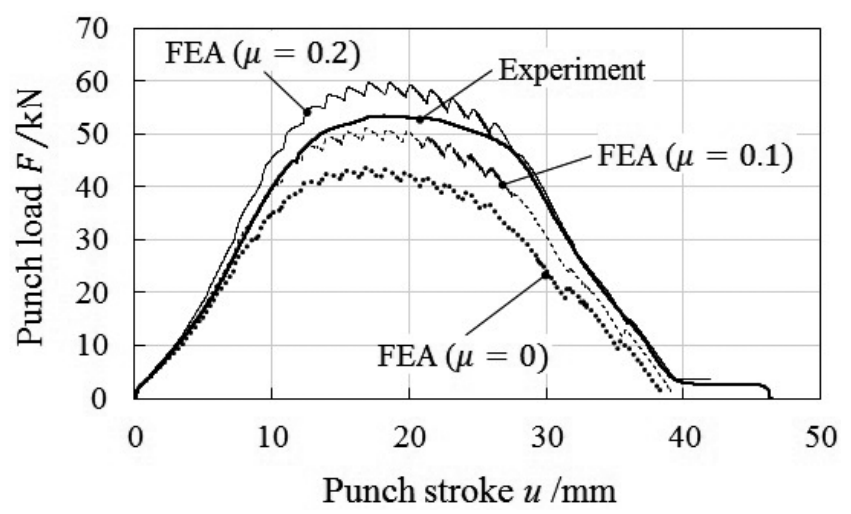

Fig. 13. Comparison between measured and analyzed results of load-stroke curves on deep-drawing test.

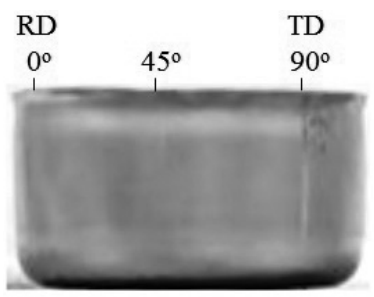

(a) Experiment

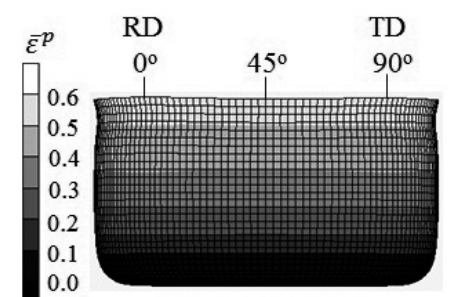

(b) $\operatorname{FEA}(\mu=0.1)$
Fig. 14. Comparison between experiment and analyzed shapes of deep-drawn cup.

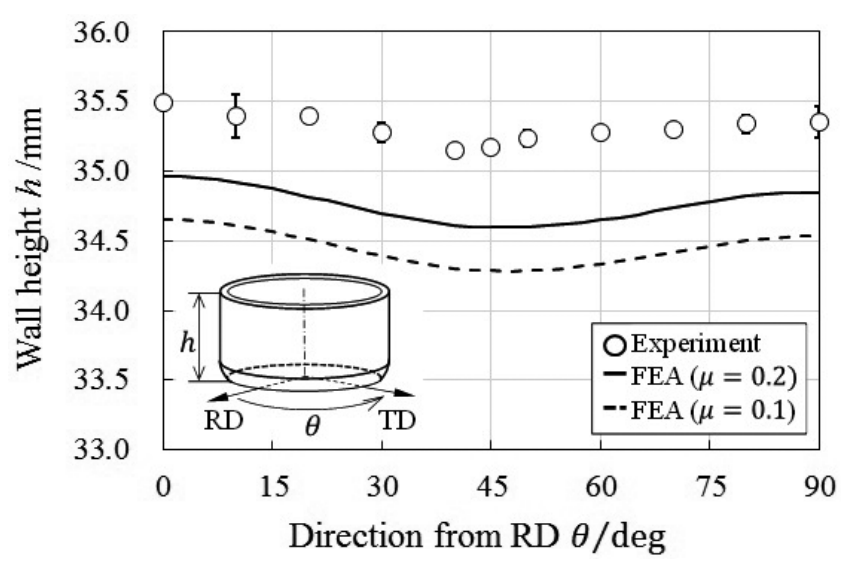

Fig. 15. Comparison between measured and analyzed results of wall height distribution.
ランジ部での引張り・圧縮が混合した応力状態で進展する。 このような違いがあるにもかかわらず, 実験結果と解析結 果は定性的な一致を示した。

\section{6. 結言}

降伏関数簡易同定法により, 鋼板の降伏曲面をモデル化 し, 信頼できる二軸応力試験の結果と比較した。また, 基 本的な板成形問題について, 同定した降伏関数を用いた解 析と実験を比較した。得られた知見を以下にまとめる。

(1) 等塑性仕事面の外接多角形から Yld2000-2d降伏関数に よってモデル化した降伏曲面と既存の二軸応力試験結 果の等塑性仕事点を比較した結果, 両者はよい一致を 示した。提案した簡易同定法により異方性降伏関数を モデル化することが可能である。

(2) 同定した降伏関数を用いて, 穴広げ試験打よび円筒深 絞り加工について有限要素解析を行い, この結果と実 験結果を比較した。いずれの成形問題でも解析は実験 の傾向を表現できた。簡易同定法による降伏関数モデ ル化は板成形解析において有効である。

（3）簡易同定法では, 液圧バルジ試験機および平面ひずみ 引張試験用の幅広チャックが必要となるが, いずれも 比較的単純な装置・治具であるため, 簡便な異方性降 伏関数同定法として利用できる。

なお，反転負荷を伴う板成形解析の高精度化には Bauschinger効果を表現できる移動硬化モデルが必要であ る。本研究では2で述べたように, 塑性仕事等価説を仮定 しているため, 移動硬化は考慮されていない。この点につ いては今後の課題としたい。

\section{謝辞}

本研究は, 平成 27 年 4 月から平成 30 年 3 月に実施された （一社）日本鉄鋼協会「先進的多軸応力試験による鋼板成形 の高度化」研究会の活動の一環として行われた。同一材料 で降伏曲面を比較できたことは本研究にとって貴重な機 会であった。多くの議論を頂戴した委員各位に謝意を表す る。また, 東京農工大学 桑原利彦教授より二軸応力試験の 実験結果を提供いただいた。ここに謝意を表する。

\section{文献}

1 ) D.Banabic: Sheet Metal Forming Process, Springer-Verlag, Berlin Heidelberg, (2010), 27.

2 ) S.Ikeda and T.Kuwabara: Tetsu-to-Hagané, 90(2004), 1016 (in Japanese). https://doi.org/10.2355/tetsutohagane1955.90.12_1016

3 ) T.Kuwabara, R.Enatsu, S.Yamagishi and F.Sugawara: Tetsu-toHagané, 98(2015), 275 (in Japanese). https://doi.org/10.2355/ tetsutohagane. 98.275

4 ) F.Yoshida: J. Jpn. Soc. Technol. Plast., 57(2016), 169 (in Japanese).

5 ) T.Uemori: J. Jpn. Soc. Technol. Plast., 57(2016), 194 (in Japanese).

6 ) T.Kuwabara and S.Ikeda: J. Jpn. Soc. Technol. Plast., 40(1999), 145 
(in Japanese).

7 ) T.Kuwabara, K.Narihara, K.Yoshida and S.Takahashi: J. Jpn. Soc. Technol. Plast., 44(2003), (in Japanese).

8 ) T.Kuwabara: Int. J. Plast., 23(2007), 385. https://doi.org/10.1016/ j.ijplas.2006.06.003

9) ISO 16842: 2014 Metallic materials - Sheet and strip - Biaxial tensile testing method using a cruciform test piece.

10) H.Aretz, O.S.Hopperstad, and O.-G.Lademo: J. Mater. Process. Technol., 186(2007), 221. https://doi.org/10.1016/j.jmatprotec.2006.12.037

11) Y.Murayama, K.Obara and K.Ikeda: J. Jpn. Soc. Technol. Plast., 35(1994), 349 (in Japanese).

12) M.-S.Aydın, J.Gerlacha, L.Kesslera and A.E.Tekkaya: J. Mater. Process Technol., 211(2011), 1957. https://doi.org/10.1016/j.jmatprotec.2011.06.018

13) H.Takizawa and S.Kodama: J. Jpn. Soc. Technol. Plast., 60(2019), 136 (in Japanese).

14) H.Nakano, T.Hakoyama and T.Kuwabara: AIP Conf. Proc., 1896(2017), 020014

15) H.Nakano, T.Hakoyama and T.Kuwabara: CAMP-ISIJ, 30(2017), 97, CD-ROM (in Japanese).

16) F.Yoshida: Dansoseirikigaku no kiso (Fundamentals of elastoplasticity), Kyoritsu publishing, Tokyo, (1997), 165 (in Japanese).

17) D.C.Drucker: Proc. first U.S. National Congr. of Applied Mechanics, American Society of Mechanical Engineers, New York, (1951), 411.

18) R.Hill and J.W.Hutchinson: J. Appl. Mech., 59(1992), S1.

19) R.Hill, S.S.Hecker and M.G.Stout: Int. J. Solids Struct., 31(1994), 2999.
20) T.Kuwabara, T.Hama, A.Ishibashi, H.Hamasaki, M.Kuroda, K.Yoshida, T.Koizumi, J.Yanagimoto, T.Wu, A.Yamanaka and H.Takizawa: Bull. Iron Steel Inst. Jpn., 24(2019), 586 (in Japanese).

21) K.Yoshida: ISIJ Int., 53(2013), 86. https://doi.org/10.2355/ isijinternational.53.86

22) R.H.Wagoner and N.M.Wang: Int. J. Mech. Sci., 21(1979), 255.

23) P.Flores, V.Tuninetti, G.Gilles, P.Gonry, L.Duchêne and A.M.Habrake: J. Mater. Process. Technol., 210(2010), 1772. https:// doi.org/10.1016/j.jmatprotec.2010.06.008

24) H.Konishi and H.Takizawa: Proc. 69th Japanese Joint Conf. for the Technology of Plasticity, Japan Society for Technology of Plasticity, Tokyo, (2018), 237 (in Japanese).

25) Y.G.An, H.Vegter and L.Elliott: J. Mater. Process. Technol., 155156(2004), 1616. https://doi.org/10.1016/j.jmatprotec.2004.04.344

26) H.Takizawa: CAMP-ISIJ, 29(2016), 25, CD-ROM (in Japanese).

27) F.Barlat, J.C.Brem, J.W.Yoon, K.Chung, R.E.Dick, D.J.Lege, F.Pourboghrat, S.H.Choi and E.Chu: Int. J. Plast., 19(2003), 1297. https://doi.org/10.1016/S0749-6419(02)00019-0

28) F.Barlat, H.Aretz, J.W.Yoon, M.E.Karabin, J.C.Brem and R.E.Dick: Int. J. Plast., 21(2005), 1009. https://doi.org/10.1016/ j.ijplas.2004.06.004

29) F.Yoshida, H.Hamasaki and T.Uemori: Int. J. Plast., 45(2013), 119. https://doi.org/10.1016/j.ijplas.2013.01.010

30) H.Takizawa, K.Oide, K.Suzuki, T.Yamanashi, T.Inoue, T.Ida, T.Nagai and T.Kuwabara: J. Phys. Conf. Ser, 1063(2018), 012099. 